DOI 10.37882/2223-2982.2021.05-3.14

\title{
МЕДИАОБРАЗ ЕВРОПЫ В АМЕРИКАНСКИХ СМИ (НА МАТЕРИАЛЕ ИНТЕРНЕТ-ИСТОЧНИКОВ)
}

\section{MEDIA IMAGE OF EUROPE IN AMERICAN MASS MEDIA}

\section{N. Pinchukova}

Summary: The subject of the study is the media image of Europe in American media. The goal of the work is to determine the features of the image of Europe in electronic versions of the leading periodicals of the United States, as well as to identify and analyze language means, actualizing the image of Europe in the US media. As a result of the study, the following conclusions were made: 1) the dominant topics are the following: "Economic Condition of Europe», where the leading place is given to the image of Europe, experiencing an economic crisis; «Internal European Problems» to which American journalists include a migration crisis, identity crisis, demographic crisis, disunity of European countries; "Relations with the United States», where Europe appears in the form of both the enemy and the ally of the United States; 2) To create a media image of Europe in the American media, the authors of the articles use various language means: stylistic techniques and intertextual inclusions (epithets, metaphors, allyusses, precedent names), emotive vocabulary, rhetorical questions; 3 ) The authors of publications form a negative image of Europe, as the media is focused mainly on negative signs of Europe.

Keywords: media image of Europe, American media, language means, topicalization.
$\mathrm{M}$ едиаобраз - понятие, мало исследованное в российской гуманитарной науке, терминологически и методологически недостаточно осмысленное. Одной из первых научных работ, посвященных данной теме, является диссертация Е.Н. Богдан «Медиаобраз России как средство консолидации общества: структурно-функциональные характеристики» [2007]. Автор определяет медиаобраз как «информационное образование (формируемое системой СМИ), находящееся между собственно социальным миром и его образом как в сознании индивида, так и в сознании общества» [1, с. 13].

Т.Н. Галинская рассматривает медиаобраз в узком значении как «фрагмент реальности, описанный в текстах только профессиональных журналистов, отражающих их мировоззрение, ценностные ориентации, политические предпочтения, а также психологические качества; в широком значении медиаобраз - это образ реальности, конструируемой во всех текстах, созданных в медиапространстве (профессиональными журналистами, блогерами, интернет-пользователями и т.д.)» $[2$, с. 91$]$.
Пинчукова Наталья Владимировна

К.филол.н., старший преподаватель, Амурский государственный университет, г. Благовещенск pinnat12@mail.ru

Аннотация: Предметом исследования является медиаобраз Европы в американских СМИ. Цель работы - определить особенности топикализации образа Европы в электронных версиях ведущих периодических изданиях США, а также выявить и проанализировать языковые средства, актуализирующие образ Европы в медийном пространстве (ША. В результате исследования были сделаны следующие выводы: 1) доминирующими топиками являются следующие: «Экономическое положение Европы», где ведущее место отводится образу Европы, испытывающей экономический кризис; «Внутренние проблемы Европы», к которым американские журналисты относят миграционный кризис, кризис идентичности, демографический кризис, разобщенность европейских стран; «Отношения с (ША», где Европа предстает в образе как противника, так и союзника (оединенных Штатов; 2) для создания медиаобраза Европы в американских СМИ авторы медиатекстов используют различные средства вербального воздействия: стилистические приемы и интертекстуальные включения (эпитеты, метафоры, аллюзии, прецедентные имена), эмотивную лексику, риторические вопросы; 3) авторы публикаций формируют негативный образ Европы, так как в СМИ делается акцент, главным образом, на отрицательных признаках Европы.

Ключевые слова: медиаобраз Европы, американские СМИ, языковые средства, топикализация.

Для данной работы актуальным представляется определение медиаобраза в узком значении, поскольку медиаобраз Европы изучается на материале публикаций, авторами которых являются профессиональные журналисты.

Итак, в данной статье под медиаобразом понимается образ реальности, конструируемый в медиатекстах профессиональными журналистами при помощи языковых средств и отражающий культурные и ценностные установки авторов-создателей текстов СМИ как представителей американского лингвокультурного сообщества.

Целью данной работы является определение особенностей топикализации образа Европы в электронных версиях ведущих периодических изданиях США, а также выявление и анализ языковых средств, актуализирующих образ Европы в медийном пространстве США.

Материалом для исследования послужили электронные версии ведущих периодических изданий США («The New York Times», «Newsweek», «Forbes», «The Washington 
Post), обладающих мировой известностью и претендующих на объективность представленных материалов. Хронологические рамки исследования охватывают 2001-2018 годы. Общий объем фактического материала составил 4115 контекстуальных примеров.

Количественные данные, являясь существенной характеристикой топикализации, выявили следующую картину. Наиболее значительное место в выборке занимают материалы, посвященные вопросам экономического положения Европы (46\%) и внутренним проблемам Европы (35\%), менее значительное - отношениям Европы с США (19\%). В скобках указано процентное соотношение статей, отражающих данную тематику. Необходимо отметить, что количественные данные в допустимой мере относительны, т.к. в ряде случаев в статье поднимается несколько тем, что затрудняет тематическую классификацию части материала.

Рассмотрим содержательную сторону данных материалов подробнее.

\section{Экономическое положение Европы}

Будучи ведущей экономической державой, США проявляет интерес к экономической деятельности других стран, в частности, своих европейских партнеров.

Анализ языкового материала позволяет утверждать, что в американской прессе создается негативный образ экономики Европы. Самой частотной лексемой, которая фиксируется практически в каждой публикации по данной тематике, является лексема crisis: economic crisis, debt crisis, fiscal crisis, financial crisis.

Наиболее продуктивным лексическим средством создания негативного представления об экономике Европы является эпитет. Например: Again, last week's European economic news looked grim (NW: 05.11.2001); stagnant economies (Forbes: 28.04.2003); Europe's lackluster economy (The WP: 11.07.2004); Many American investors seem to have written off Europe as a quaint low-growth low-return destination (Forbes: 01.11.2005); a cash-strapped Europe (NW: 01.11.2008); The European Union says it is facing a "deep and protracted recession" with government spending the only source of growth this year (Forbes: 23.01.2009); The European debt crisis is the most urgent crisis facing the global economy (Forbes: 30.09.2011); crisis-hit Europe (The WP: 28.10.2013); Europe's poor economy (Forbes: 25.09.2014).

Кроме того, для формирования образа европейской экономики в СМИ США активно используется метафора, которая является одним из наиболее удачных способов создания образов в сознании, поскольку «механизм метафорического переноса основывается на ассоциативно-образной природе человеческого мышления» [3, с. 23]. Метафора воздействует на всех уровнях - рациональном и эмоциональном, что гарантирует получение сообщения адресатом. Конечной целью функционирования метафоры в медиадискурсе является формирование образа, мнения, мировосприятия посредством эмоционального и рационального воздействия [Там же].

Представление об экономическом кризисе в Европе реализуется посредством концептуальной метафорической модели «Экономический кризис в Европе - это болезнь». Например, Europe faces multiplying economic headaches (Forbes: 12.03.2009); Europe is in the doldrums (Forbes: 25.07.2005).

Так, в статье «Europe's financial contagion» (The WP: 18.07.2011) экономические проблемы сравниваются с вирусом, которым по очереди заражаются европейские страны: Greece sneezed, and now most of Europe has a cold. The European debt crisis has already spread like a virus from Greece to Ireland and Portugal, and other countries are now at risk (The WP: 18.07.2011).

Также используется метафорическая модель «Экономический кризис в Европе - это стихийное бедствие»: Much of Europe is mired in economic stagnation, which has made people fearful of the future and more hostile to change and innovation (Forbes: 25.07.2005); The economic crisis that has swept Europe (NW: 17.07.2011); As the sovereign debt crisis in Europe roars on ... (Forbes: 09.11.2011).

В следующем примере метафорическое выражение a financial black hole, используемое для характеристики финансового положения Европы закрепляет в сознании читателей представление о финансовом коллапсе, грозящем региону: Europe day by day becomes a financial black hole, with matter from the periphery being sucked toward the center until the vortex itself collapses (NW: 26.12.2011).

В единичных случаях американские журналисты используют прецедентные имена: Europe is sinking, but the U.S. has no life rafts on its Titanic (Forbes: 28.11.2011). Образ тонущего Титаника подчеркивает катастрофическое состояние европейской экономики, формируемое у реципиентов.

Наряду с медиаобразом Европы, переживающей экономический кризис, в американских СМИ формируется представление о Европе, испытывающей экономический рост.

Экономика Европы испытывает резкий рост: Europe's economy may be booming (NW: 18.06.2012).

Авторами публикаций отмечается экономический рост в европейских странах за последние годы, который 
в языке объективируется существительными с семой «возрождение»: The even bigger surprise is the German-led revival of Europe's economy (NW: 04.06.2007); But the world's economic picture will be better than what it has been in years, thanks to the resurgence of Europe (NW: 18.06.2012); a European economic renaissance (NW: 04.06.2018).

Американские журналисты подчеркивают превосходство Европы над США в экономической сфере. If the reports are on target, Europe will grow faster than America in 2007-for the first time in six years (NW: 05.05.2007); Euroland will likely outperform the U.S. economy for the first time in recent history (NW: 04.06. 2007): It's a bitter moment: after decades of stagnation, Europe was suddenly looking more economically powerful than America (Forbes: 28.09.2017).

Европа представляется как мировая супердержава, не имеющая себе равных по силе экономического влияния: Europe is now a global superpower of world-historical importance, second to none in economic clout (NW: 26.03.2016).

Идея экономического подъема Европы актуализируется также при помощи метафор. Так, в статье, посвященной экономической ситуации в регионе, Европа предстает в образе ракеты, чья траектория направлена вверх: If anything, Europe's trajectory is up, not down (NW: 26.03.2007). Реализуется идея о том, что Европа - это главный мировой капитал: But Europe remains the wheel capital of the world (NW: 12.08.2002).

\section{Внутренние проблемы Европы}

Резкий приток мигрантов в Европу, обусловленный непрекращающимися конфликтами в Сирии, Пакистане, Афганистане, начался в июне 2015 года. Однако и ранее европейские страны сталкивались с проблемами миграции. Публикации, посвященные данной проблеме, встречаются в американских СМИ на протяжении всего исследуемого периода (с 2001 по 2018 год): Europe may still resist the idea that it is a Continent of immigrants. But in order to thrive, it has no choice but to become one (NW: 19.02.2001); Europe is also likely to turn to immigration to help replenish its shrinking work force (NW: 26.03.2007); Europe Moves to Open Doors to More Refugees (Forbes: 02.09.2009); In recent decades Europe has received as many immigrants as the U.S., but it has proven far less able to absorb them (Forbes: 02.02.2010); Immigration backlash is on the rise in Europe (Forbes: 31.03.2014). Тем не менее в 2015 году во время обострения миграционного кризиса количество медиатекстов, посвященных данной тематике, резко увеличилось.

Авторы статей по данной тематике констатируют факт, что, в отличие от США, Европа не в состоянии принять большое количество мигрантов: In recent decades Eu- rope has received as many immigrants as the U.S., but it has proven far less able to absorb them (Forbes: 02.02.2010). Кроме того, европейские страны в условиях миграционного кризиса отказываются от роли убежища для беженцев и от своей ответственности перед ними: Refugee Crisis Shows Europe Refuses Both Safe Haven Role And Responsibilities (Forbes: 01.09.2015).

Однако, по мнению американских журналистов, у Европы нет другого выбора как стать континентом иммигрантов, что поможет в решении ее экономических проблем: Europe may still resist the idea that it is a Continent of immigrants. But in order to thrive, it has no choice but to become one (NW: 19.02.2001); Europe is also likely to turn to immigration to help replenish its shrinking work force (NW: 26.03.2007) If international opprobrium doesn't prod Europe to throw open its doors, there are signs that economic selfinterest will (NW: 19.02.2001).

Наиболее частотными лексическими единицами, актуализирующими данный признак, являются: immigration dilemma, migration crisis, refugee crisis: Culture and Economy Clash in Europe's Immigration Dilemma (NW: 19.02.2001); Europe's Migration Crisis Isn't about Poverty, It's About Rising Wealth (Forbes: 05.09.2015); Refugee Crisis: Why Are Europe's Leaders Failing? (Forbes: 22.09.2015).

Часто встречающееся стилистическое средство, которое формирует образ Европы, испытывающей наплыв мигрантов - метафора. Прибывающие беженцы сравниваются с поднимающейся волной, неостановимым водным потоком: $a$ urising tide» of immigrants from Africa and the East (NW: 01.10.2016); the unstoppable flow of illegal immigrants (Forbes: 05.07.2015).

По мнению американских журналистов, Европа переживает кризис идентичности. В самом общем понимании идентичность означает «осознание принадлежности объекта (субъекта) другому объекту (субъекту) как части и целого, особенного и всеобщего. Главным характерным признаком и основанием данного понятия является тождественность самому себе» [4, с. 154].

Что касается европейской идентичности, то это своего рода многокомпонентное коллективное сознание Европы, обусловленное многими факторами - географическими, культурными, социально-историческими, правовыми, экономическими, идеологическими, ценностными [5, с. 215].

Наиболее частотными стилистическими средствами, используемыми для актуализации данного медиаобраза, являются риторические вопросы, метафоры, эпитеты.

Например: The ultimate question here is identity. Is Europe a geography, or an idea? Should belonging depend on culture, 
tradition and history, as Giscard would have it? Or should it spring from shared values? These are open-ended questions. If Turkey were admitted, why not Russia - or even Tunisia or Morocco? (NW: 23.12.2002). Автор задает риторические вопросы: Что такое Европа: географическое понятие или идея? Что определяет принадлежность к европейской цивилизации: общая культура, традиции и история или общие ценности?

Высказывается мнение, что старая Европа умирает, поскольку ее представление о себе, ее культура и ее ценности изменились: No, the old Europe is dying because its idea of itself, its culture and what it stands for has changed (NW: 23.12.2002). It is fashionable these days to speak of the death of Europe (Forbes: 03.04.2007). В данных примерах используется метафора.

Увеличение количества мигрантов на протяжении последних десятилетий привело к тому, что Европа из «Христианского клуба» превращается в мультикультурный плавильный котел (метафора): Immigration will transform Europe over the coming decades, making it less a Christian club than a multicultural melting pot - not as teeming as America, perhaps, but nonetheless a place of growing cultural complexity (NW: 23.12.2002).

Использование эпитета diverse актуализирует культурную неоднородность Европы: Europe is getting more diverse by the day (Forbes: 15.02.2016).

Кризис идентичности в Европе выражается в борьбе между секуляризмом и исламизмом: ... now we could be at a critical juncture in the struggle between secularism and Islamism (NW: 08.10.2001). Высказывается мнение, о том, что невозможно совместить ислам и европейские ценности: more people in the political mainstream are arguing that Islam cannot be reconciled with European values (The NYT: 10.10.2006).

Иногда авторы публикаций прибегают к аллюзии: The need now is for Western Europe to find ways in which its secular traditions can coexist not just with those of the Continent's traditional faiths, but with those that have, 500 years after the reconquista, returned to its shores. Islam is in Europe to stay (NW: 01.10.2006). Реконкиста (исп. отвоевание) - движение за освобождение Испании от арабского влияния, продолжавшееся с VIII-IX вв. до конца XV в.

В американских медиатекстах создается медиаобраз Европы, испытывающей демографический кризис.

Данный образ реализуется при помощи употребления в текстах словосочетаний aging population, an aging Europe, low birthrates: Easing entry requirements makes good economic sense, since Europe needs 75 million new workers over the next 50 years to replenish its aging population
(Forbes: 19.02.2001); An Aging Europe May Find Itself on the Sidelines (The NYT: 29.06.2003); We understand perfectly well that Europe is in trouble because its low birthrates mean fewer workers, and that means less economic growth (NW: 27.09.2010).

Также в статьях, анализирующих демографическую ситуацию в Европе, используются эпитеты dismal, sclerotic: And given Europe's dismal demographics and growth projections, its likely that there never will be (NW: 04.05.2009); It is conceivable that America's lead, especially over an aging and sclerotic Europe, will actually increase over the next two decades (NW: 24.03.2003). Формируется представление о Европе, имеющей удручающие демографические показатели.

В американских СМИ формируется образ разобщенной Европы.

Языковая реализация медиаобраза происходит за счет употребления лексем с семами «разделение», «распадаться», «раскол», «разобщать»: European Disunion (The NYT: 22.03.2010); As the E.U. pursues closer integration, its member states are lining up on either side of two great divides (Forbes: 21.09.2003); Europe Splits (NW: 10.02.2003); The EU's inability to come together leaves it vulnerable to still more division (NW: 10.09.2007); But Europe, which was to have become a mammoth actor on the world stage, showed itself to be a disunited continent (NW: 24.02.2003); Europe's new dividing line; The battle of North vs. South replaces East vs. West (The WP: 07.09.2010).

Кроме того, для формирования образа распадающейся Европы также используется аллюзия. Например: Obama was supposed to put together the European Humpty Dumpty that President Bush shattered by favoring alliances of the willing over old alliances (The NYT: 06.09.2010). ШалтайБолтай - хорошо известный англоязычному читателю герой детских стихов. В современном английском языке словосочетание «шалтай-болтай» имеет два значения: «толстячок-коротышка» и «вещь, упавшая или разбитая и невосстанавливаемая». Очевидно, что в приведенном примере данное выражение употребляется во втором значении, то есть американские СМИ констатируют тот факт, что Европа является разобщенной и не стремится к объединению.

В следующем примере используется два стилистических средства: метафора и аллюзия: If we believe the Cassandras, the European Union is now teetering on the brink of collapse (The NYT: 25.06.2013). Для того чтобы изобразить Европейский союз, находящийся на грани разрушения, используется метафора to teeter on the brink of collapse («балансировать на грани развала»). Также в данном примере используется аллюзия the Cassandras - Кассандра (греч. миф.) - прорицательница. 
В американской прессе выражается озабоченность по поводу возрастающей террористической угрозы в Европе: U.S. issues travel alert for Americans in Europe as terrorism threat grows (The WP: 04.10.2010). Главной угрозой европейской безопасности журналисты считают джихадистов, мигрирующих в Сирию: Jihadi fighters migrating to Syria are a major security threat to Britain, Europe, and beyond (The WP: 24.10.2013).

Авторы публикаций отмечают, что террористические акты 11 сентября 2001 года, совершенные в США, ввергли Европу в атмосферу настороженности и беспокойства: Then the terror attacks of Sept. 11, 2001, jolted Europe into new awareness and worry (The NYT: 11.10.2006).

В ряде материалов используются метафоры, посредством которых создается негативный медиаобраз Европы, используемой террористами в своих целях (как площадка для вербовки новых сторонников, как перевалочная база): Europe became a fertile recruiting ground for Mr. bin Laden and Al Qaeda (The NYT: 22.03.2004); Eventually, Europe became a staging area for terrorism - most notably the Sept. 11 attacks, planned in Germany and Spain (The NYT: 22.03.2004).

После терактов в Париже 13 ноября 2015 года закономерно увеличилось количество медиатекстов, посвященных данной тематике. Журналисты подчеркивают, что случившаяся трагедия раскрывает фатальные ошибки в обеспечении европейской безопасности: Failure to stop Paris attacks reveals fatal flaws at heart of European security (The WP: 28.11.2015). Для описания самих терактов используются эпитеты с экспрессивной коннотацией: the horrific terror attacks; the deadliest attacks; the deadly attacks, которые усиливают эмоциональное впечатление читателей от рассказа о драматических событиях.

\section{Отношения с США}

Тематическая область «отношения с США» локализована двумя основными топиками: Европа-противник США и Европа-союзник США.

Для актуализации образа «Европа - противник США» довольно часто используются метафоры. America's decades-old joust with Europe over farm subsidies (NW: 12.11.2001); The more certain Europe is that the United States will do the dirty business on its own, the more vehemently Europe will shake its head in disapproval (The NYT: 03.03.2003); Ever since McCain chose Sarah Palin as his running mate, Europe has looked down its collective nose at the thought of a McCain presidency (NW: 10.11.2008).

Авторы медиатекстов, характеризуя образ «Европапротивник США» активно применяют лексику с эмоционально-экспрессивной коннотацией: stubbornly indepen- dent, The Un-American, most energetic opponent: Europe has long defined itself as The Un-American, stubbornly independent from the world hegemon (NW: 23.12.2002); Europe, instead of being America's leading partner, will become its most energetic opponent (The NYT: 24.02.2003).

Употребление разговорной лексики придает описанию отношений Европы и США аффективно-эмоциональную окраску: Will differences on peacekeeping and missile defense push Europe and America apart? (Forbes: 29.01.2001) Do you wonder why Europe and the Third World turn against the United States? (NW: 07.04.2003).

Негативное отношение европейцев к США подчеркивается лексемой disdain (презрение): Europeans love thinking about America, part in longing, part in envy, part in disdain (Forbes: 20.11.2008); European disdain for the United States is centuries old, of course (NW: 09.08.2010).

Образ «Европа-союзник США» создается, в первую очередь, при помощи метафор. Например, метафора joined hands подчеркивает единство США и Европы в отношении Ирана: Europe has now joined hands with the United States and is offering Iran a choice - nuclear weapons or normal trade, but not both (NW: 06.12.2004).

Метафорические выражения conjoined twin, our European brethren подразумевают неразрывность связей между двумя союзниками: Europe is our conjoined twin (Forbes: 30.06.2005); No matter which party is in power, America treats Muslims--and all races and religions--with as much, if not more, dignity and respect than many of our European brethren (Forbes: 12.01.2017).

Авторы пишут о том, что европейские лидеры готовы похоронить антиамериканизм, популярный в Европе в начале XXI века: By going against the public grain at obvious political risk, Europe's leaders are demonstrating just how determined they are to bury anti-Americanism (NW: 10.09.2018). В то же время страны Центральной и Восточной Европы демонстрируют проамериканизм: Similarly, the countries of Central and Eastern Europe are exhibiting such rampant pro-Americanism that Moscow, their old master, is growing restive (NW: 10.09.2007). Эпитет rampant («неистовый») усиливает контекстную эмоциональную окраску.

В следующем примере создается образ Европы и Америки, объединившихся во имя будущего: Europe and America, Aligned for the Future (The NYT: 18.11.2010).

Таким образом, анализ языкового материала позволяет сделать вывод, что с целью воздействия на реципиентов американские авторы медиатекстов используют различные языковые средства выразительности. Ниже в Таблице 1 представлено процентное соотношение языковых средств выразительности в медиатекстах, связанных с темой «Европа» в прессе США. 
Таблица 1 Языковые средства выразительности, используемые в СМИ США

\begin{tabular}{|l|c|}
\hline эпитет & $44 \%$ \\
\hline метафора & $36 \%$ \\
\hline эмотивная лексика & $10 \%$ \\
\hline аллюзия & $6 \%$ \\
\hline прецедентные имена & $2 \%$ \\
\hline риторические вопросы & $2 \%$ \\
\hline
\end{tabular}

Как показано в Таблице 1, наиболее частотными языковыми средствами выразительности в прессе США являются эпитет и метафора. Существенно в меньшей степени представлены эмотивная лексика, аллюзия, прецедентные имена, риторические вопросы.

В связи с этим можно констатировать, что для создания языкового образа Европы в американских СМИ авторы медиатекстов используют различные средства вербального воздействия: стилистические приемы и интертекстуальные включения (эпитеты, метафоры, аллю- зии, прецедентные имена), эмотивную лексику, риторические вопросы.

Необходимо отметить, что наряду с языковыми средствами, тематическое разворачивание образа Европы также является средством создания ее медиаобраза в американских СМИ. Доминирующими топиками являются следующие: «Экономическое положение Европы», где ведущее место отводится образу Европы, испытывающей экономический кризис; «Внутренние проблемы Европы», к которым американские журналисты относят миграционный кризис, кризис идентичности, демографический кризис, разобщенность европейских стран; «Отношения с США», где Европа предстает в образе как противника, так и союзника Соединенных Штатов.

Итак, проанализировав содержание медиаобраза Европы в американских СМИ, мы приходим к выводу, что авторы публикаций формируют негативный образ Европы, так как в СМИ делается акцент на одних признаках Европы (главным образом, отрицательных), в то время как другие остаются в «тени».

\section{ЛИТЕРАТУРА}

1. Богдан Е.Н. Медиаобраз России как средство консолидации общества: структурно-функциональные характеристики: автореф. дис. ... канд. филол. наук. M., 2007.25 c.

2. Галинская Т.Н. Понятие медиаобраза и проблема его реконструкции в современной лингвистике // Вестник Оренбургского государственного университета. 2013. № 11 (160). С. 91-94.

3. Ермоленко Г.М. Медиаобраз В.В. Путина в текстах англоязычных СМИ // Вестник Волжского ун-та им. В.Н. Татищева. 2013. №3(13). С. 21-28.

4. Садохин А.П., Грушевицкая Т.Г. Этнология. М.: Академия; Высшая школа, 2000. 304 с.

5. Серебрякова С.В. Научное осмысление понятия «европейская идентичность» в современном общеевропейском контексте // Гуманитарные и юридические исследования. Научно-теоретический журнал. 2017. № 1. С. 213-218.

(с) Пинчукова Наталья Владимировна (pinnat12@mail.ru). 